\title{
Trends in the effects of climate change on terrestrial ecosystems in the Republic of Korea
}

\author{
Sei-Woong Choi', Woo-Seok Kong ${ }^{2}$, Ga-Young Hwang ${ }^{3}$ and Kyung Ah Koo ${ }^{4^{*}}$ (D)
}

\begin{abstract}
In this review, we aimed to synthesize the current knowledge on the observed and projected effects of climate change on the ecosystems of Korea (i.e., the Republic of Korea (ROK) or South Korea), as well as the main causes of vulnerability and options for adaptation in these ecosystems based on a range of ecological and biogeographical data. To this end, we compiled a set of peer-reviewed papers published since 2014. We found that publication of climate-related studies on plants has decreased in the field of plant phenology and physiology, whereas such publication has rapidly increased in plant and animal community ecology, reflecting the range shifts and abundance change that are occurring under climate change. Plant phenology studies showed that climate change has increased growing seasons by advancing the timing of flowering and budburst while delaying the timing of leafing out. Community ecology studies indicated that the future ranges of cold-adapted plants and animals could shrink or shift toward northern and high-elevation areas, whereas the ranges of warm-adapted organisms could expand and/or shift toward the areas that the aforementioned cold-adapted biota previously occupied. This review provides useful information and new insights that will improve understanding of climate change effects on the ecosystems of Korea. Moreover, it will serve as a reference for policy-makers seeking to establish future sectoral adaptation options for protection against climate change.
\end{abstract}

Keywords: Climate change, Projected effects, Korea, Ecosystem, Phenology, Diversity

\section{Background}

Climate change has a wide range of continuous repercussions on ecosystems. Importantly, if the biodiversity of an ecosystem, i.e., the presence of a wide variety of organisms, were lost, this loss would be permanent. However, unlike situations in other socioeconomic fields, climate change-related effects on ecosystems may be beyond the public interest since the difficulties they cause may not directly damage or inconvenience humans (Park et al. 2019). However, it is commonly accepted knowledge that ecosystems are currently experiencing burdensome and disturbing situations.

\footnotetext{
* Correspondence: kyungah.koo@gmail.com

${ }^{4}$ Division for Natural Environment, Water and Land Research Group, Korea Environment Institute, Sejong 30147, Republic of Korea

Full list of author information is available at the end of the article
}

More than many other parts of the world, Korea has been greatly affected by climate change mainly due to its higher consumption of fossil fuels that support rapid urbanization and industrialization (Korea Meteorological Administration (KMA) 2012). The most distinct change in the Korean climate is an increase in the range of temperature fluctuations throughout the seasons (Chung et al. 2004; National Institute of Meteorological Sciences (NIMS) 2018). The number of record minimum temperature days has decreased rapidly, whereas the maximum precipitation during the summer has increased (Jung et al. 2004; Kim et al. 2007; National Institute of Meteorological Sciences (NIMS) 2018). Up to now, the ministry of Environment of Korea has published two volumes of the Korean Climate Change Assessment Report in 2011 and 2015 which covered the ecological

(c) The Author(s). 2021 Open Access This article is licensed under a Creative Commons Attribution 4.0 International License, which permits use, sharing, adaptation, distribution and reproduction in any medium or format, as long as you give appropriate credit to the original author(s) and the source, provide a link to the Creative Commons licence, and indicate if changes were made. The images or other third party material in this article are included in the article's Creative Commons licence, unless indicated otherwise in a credit line to the material. If material is not included in the article's Creative Commons licence and your intended use is not permitted by statutory regulation or exceeds the permitted use, you will need to obtain permission directly from the copyright holder. To view a copy of this licence, visit http://creativecommons.org/licenses/by/4.0/. 
responses related with climate change up to the year of 2013. The Korean Climate Change Assessment Report 2020 (KCCAR 2020; Bae et al. 2020), the third report of its kind, was published as a compilation of studies accumulated over the past 6 years from various sectors including water resources, ecosystem services, forestry, and agriculture industries as well as from the fields of energy, health, human settlement, and welfare, and from adaptation policies and plans. Here, we revise the ecosystem chapter of the Climate Change Impact and Adaptation in KCCAR 2020.

This review synthesizes the current knowledge on the observed and projected effects of climate change in Korean ecosystems, as well as on the main causes of vulnerability and options for adaptation in these ecosystems, from a wide range of ecological and biogeographical data. Our aim was to provide useful information and new insights that improve understanding of the effects of climate change on Korean ecosystems and supply a reference for policy-makers with which to establish future sectoral adaptation options to protect against climate change.

\section{Materials and methods}

To address our aims, we reviewed the observed changes in biota, including phenology, distribution change, diversity change, species composition, and physiological or genetic change, as well the vulnerability of ecosystems to climate change and the effects of change determined via modeling, along with future prospects. Specifically, to assess observed climate change effects in Korea and help to avoid possible negative consequences from climate change on Korean ecosystems, as well as establish adaptation strategies suited to Korea, we compiled a set of peer-reviewed papers and reports published since 2014 . Consequently, we were able to summarize the results of the latest domestic and overseas research on the climate change effects related to the Korean peninsula and possible adaptations to these effects. Furthermore, we created a database using the compiled results on effects and adaptations.

\section{Results and discussion}

\section{Ecosystems: habitat}

The threat factors of climate change against biota were selected for the subalpine region, inland wetland, and coastal ecosystems, which are the major ecosystems in Korea vulnerable to climate change.

\section{Terrestrial area}

The climate zone of the Korean peninsula was classified by applying the warmth index and Köppen climate classification based on electromagnetic climate data from 30 -year normal climate data of the entire region; future changes to climate zone were predicted under the Representative Concentration Pathway (RCP) 8.5 scenario (Kim et al. 2017a). The subtropical zone is predicted to expand northward and upward dramatically whereas the alpine belt will shrink substantially. In addition, 75\% of Korea is expected to belong to the dry-winter humid subtropical climate zone (Köppen climate zone of Cwa) while $\sim 25 \%$ will belong to the humid subtropical climate zone (Köppen climate zone of $\mathrm{Cfa}$ ). These results were obtained under a rather extreme scenario of RCP 8.5 , but they indicate that climate patterns that vary by region can gradually be simplified (Kim et al. 2017a).

Using the basic statistical data from national parks and the RCP 8.5 scenario, a climate change vulnerability assessment was conducted for 21 national parks nationwide; types of vulnerability were evaluated and classified based on climate exposure, sensitivity, and adaptability (Kim and Kim 2016). The findings suggest that it is desirable to prepare adaptation measures that reflect the climate characteristics of each region because differences in climate exposure, sensitivity, and adaptation capacity exist according to the regional climate environments of national parks.

By analyzing 10-year (2003-2012) meteorological observation data and future climate change scenario data obtained from high-resolution regional climate models, forecasts for change until the late twenty-first century (2071-2100) in the Mt. Hallasan alpine area, where climate change caused by anthropogenic effects appears vertically, were analyzed (Choi 2017). Results indicate that the subtropical climatic zones will be extended to mid-altitudes by the end of the twenty-first century due to decreased cold stress in winter, with the possibility that the range of subtropical climatic zones will expand because of increased high-temperature stress in summer in mountainous regions. This finding is meaningful because it complements limited data from automatic weather observation networks by suggesting the possibility of continuous climate zone movement through analysis of high-resolution modeling data. In addition, it implies that increased effort to preserve the species diversity of subalpine ecosystems will be necessary in the late twenty-first century and that continuous research on climate factors other than temperature and changes in climate phenomena are required.

\section{Rivers and wetlands}

Urban rivers, which are in a poor environmental condition due to overpopulation and industrialization, are more vulnerable to internal and external factors (Lee et al. 2017). Research indicates that environmental disturbance caused by local climate change-related drought and torrential rain negatively affects water quality and diatom communities in urban rivers, as well as the structure and function of aquatic ecosystems. 
The land cover change in areas of mountainous wetland was confirmed using multitemporal aerial photographs and climate data from 1975 to 2012, with results showing that anthropogenic effects, such as golf course construction, and a rapid increase in mean annual temperature since 1980 had altered flora distribution and reduced wetland area (Jang and Kim 2013). In particular, it was judged that the increase in the average temperature in spring caused the drying of the soil moisture in the study area, which affected the incubation of the wetland.

\section{Coastal region}

The coastal region is a vulnerable ecosystem that will be directly affected by sea level rise from climate change (Lee et al. 2006; Yu et al. 2016; Moon et al. 2017). The effects of climate change on coastal and island areas can be organized based on climate change scenarios as follows (Choi and Park 2018): (1) lowland flooding due to sea level rise, wetland loss, inflow of seawater, and collapse of the living quarters of inhabitants; (2) physiological characteristics of organisms and behavior, ocean acidification, and coral reef destruction that affect population dynamics, and economic damage to local residents due to reduced levels of fish and shellfish; and (3) reduction of available water resources due to increased salt concentrations such as penetration of groundwater by saltwater.

The salt marsh, which has a mixture of terrestrial and marine ecological characteristics, has a unique ecosystem with environmental value and limited distribution of plants due to high salt concentrations (Kim and Myeong 2014). Changes in climate and soil environments were traced in the halophyte habitats of Suncheon Bay, and basic monitoring data on the characteristics of halophyte habitats and changes in environmental factors were obtained. Comparison of the environmental variables (temperature, precipitation, relative humidity, and sunshine duration) between data from the past 40 years (1973-2013) and the last 4 years (2010 through 2013) showed that despite temperature increasing significantly and relative humidity and precipitation decreasing significantly, there was no significant change in sunshine duration. Among the soil environment factors that were affected by climate, $\mathrm{pH}$, soil moisture content, salinity, and electrical conductivity all significantly increased whereas organic matter content significantly decreased. In a simulation using the Intergovernmental Panel on Climate Change (IPCC)'s sea level rise scenario, the area of salt marshes is predicted to decrease by $20-45 \%$ in 2100 compared with the present area. Such changes in ecosystems are expected to have negative effects not only on biodiversity but also on ecosystem services; thus, appropriate responses and management measures are essential.

\section{Ecosystem: biota in the current state Phenology}

Many studies have focused on how climate change affects the growing season and phenology of plants (Hur et al. 2014; Hur and Ahn 2015; Ahn et al. 2016; Choi et al. 2016; Lee et al. 2018). Plant phenology studies have been mainly conducted at the monitoring level at the long-term ecology research sites of national research institutes. A few studies conducted correlation analyses between plant phenology and temperature, such as correlations between temperature and temporal changes in the timing of flowering and budburst. In one study, the timing of budburst was estimated over an entire Korean forest using satellite imaging; the timing was highly correlated with April mean temperature and the average temperature of the budburst date $\left(3{ }^{\circ} \mathrm{C}, 12\right.$ days) (Choi et al. 2016). The timing of flowering and leafing out of five subalpine plant species, Lilium cernuum, Primula modesta var. hannasanensis, Trientalis europaea subsp. arctica, Ligusticum tachiroei, and Disporuum ovale, was investigated in Mt. Gayasan for 5 years from 2012 to 2016, and the flowering time of these five plant species was highly correlated with the daily maximum temperature and the daily mean temperature (Sung and Kim 2018).

The change in the growing season was analyzed at a national scale with data collected at 19 meteorological stations in Korea from 1970 to 2013 (Jung et al. 2015). These analyses showed that the length of the growing season increased by an average of 4.2 days/10 years due to advance of budburst timing (an average of 2.7 days/10 years) and leafing out was delayed by an average of 1.4 days/10 years (Jung et al. 2015).

On the other hand, a local scale study conducted in an urban area, Suwon City, reported an increase in the growing season of approximately 6.8 days $/ 10$ years due to the advanced timing of budburst ( $~ 4.1$ days/10 years) and a delay in the timing of leafing out $(\sim 2.7$ days/10 years) (Jung et al. 2014). Another local scale study conducted on a spruce community in a mountains area, Mt. Gyebangsan, also showed that climate change between 1972 and 2006 advanced the start date of spruce growth and delayed the end date, resulting in an increase in the growing season of spruce; however, this increase in growing season was not statistically significantly correlated with spruce growth (Jang et al. 2015).

The effects of climate change on plant growth and physiology have been predicted by exploring changes in the growth of plants under increased $\mathrm{CO}_{2}$ and temperature in conjunction with other environmental factors such as soil moisture and nutrients. Sarcandra glabra showed an increased resistance to soil organic matter content and moisture conditions in a warming environment, suggesting that these factors do not limit 
the growth of this species under these conditions (Lee et al. 2018). The growth of Bupleurum latissimum was more sensitive to the increased $\mathrm{CO}_{2}$ and temperature than to other environmental conditions, e.g., light, moisture, and nutrients; its maximum growth increase occurred when nutrients, $\mathrm{CO}_{2}$, and temperature were increased (Ahn et al. 2016).

\section{Changes in diversity and distribution range}

Plants Species range shifts have been analyzed according to elevational gradient; such analysis provides fundamental data for predicting climate change effects on species compositions and range dynamics. Climate change-related range shifts in plants were mostly predicted at the regional scale, i.e., the Korean peninsula, but rarely at local scales, e.g., mountain areas. Such predictions have been made for climate change-sensitive species (Shin et al. 2018; Koo et al. 2015; Koo et al. 2016; Park et al. 2016b; Koo et al. 2017b; Koo et al. 2017c; Koo et al. 2018; Park et al. 2019).

Using time-series satellite image analysis for 20 years since the mid-1990s, long-term area changes of coniferous forests in subalpine regions nationwide were considered according to climate change data (Kim et al. 2019a). The area of coniferous forests decreased by about $25 \%$ over 20 years; thus, the fragility of highland ecosystems was particularly high. According to climate factors, annual average temperature had a greater effect than other factors on changes in the coniferous forest area.

The proportion of cold-adapted plants, such as alpine and subalpine plants, distributed in high-elevation areas of Mt. Jirisan and Mt. Gayasan increases at higher elevations, whereas rare and endemic plants decrease (Kim et al. 2018a; Kim et al. 2017b). The species diversity of vascular plants generally decreases as elevation increases at Mt. Taebaeksan (An et al. 2019). When considering human disturbances, the proportion of forest-growing plants increases as elevation increases but the number of plants growing in disturbed areas decreases (An et al. 2019). Cold-adapted evergreen broad-leaved trees, which mainly inhabit alpine and subalpine areas, have been predicted to decrease under climate change and could only remain in alpine regions of the Democratic People's Republic of Korea (DPRK) or North Korea (Fig. 1; Koo et al. 2015).

Most studies related to growth change under climate change were conducted for Abies koreana, a subalpine coniferous species that may be highly sensitive to climate change. Dendroecological studies showed that the growth of $A$. koreana was negatively correlated with drought stress during spring in Mt. Hallasan, suggesting that such stress (caused by decreasing precipitation and increasing temperature in winter and spring) would be a major driver of growth decline and death of the species (Seo et al. 2019b). Additionally, studying other climate change-related events, such as typhoons, strong winds, and soil erosion, could also be important for understanding the effects of climate change on A. koreana growth (Kim et al. 2019b; Seo et al. 2019a; Seo et al. 2019b).

Few studies have focused on the effects of climate change on the dynamics of population genetics (Kim et al. 2015a). Understanding population genetic diversity and its change in relation to climatic factors is fundamentally important for determining the adaptation ability of plants to climate change. Data were collected through amplified fragment length polymorphism analysis of 12 populations of Sasa borealis nationwide (Kim et al. 2015a). The genetic diversity of $S$. borealis populations decreased as latitude increased, suggesting that climatic warming has negative effects on the species. The effects of climate change on the production of secondary metabolites and gene expression have been mostly investigated by national research institutes, such as the National Institute of Ecology and National Institute of Forest Science; however, results have yet to be published in related journals. Indeed, research into climate change effects on the production of secondary metabolites has only recently been initiated.

Animals Many studies have estimated climate changerelated population changes (increases or decreases) in invertebrate and vertebrate animals. With global warming, many animal species have shown changes in population abundance or range expansion. Climate factors are major drivers of diversity changes in arthropods (Lee et al. 2016). Additionally, in studies from forest areas, elevation was found to be a strong explanatory variable for changes in diversity. Since Korea is a peninsula, the decreasing rate of the northern species was much higher than the increasing rate of southern species. It could be postulated that global warming will decrease total species diversity and abundance in Korea over time.

Kwon et al. (2014a) compared the distribution range of butterfly species before (1938-1950) and after (19962011) the Korean War. They found that the northern border line of southern species moved northward as well as southward of the southern border line of northern species. In addition, the distribution range had moved $1.6 \mathrm{~km}$ per year during the last 60 years. The authors concluded that this expansion of northern species was a result of warming as well as forest growth.

In high-elevation areas in Mt. Hallasan, Yeongsil (1280 $\mathrm{m})$ to Baengnokdam $(1950 \mathrm{~m})$, the alpine and subalpine belt of the mountain has a large number of northern butterflies (Kim et al. 2014). The largest number of 
(a)

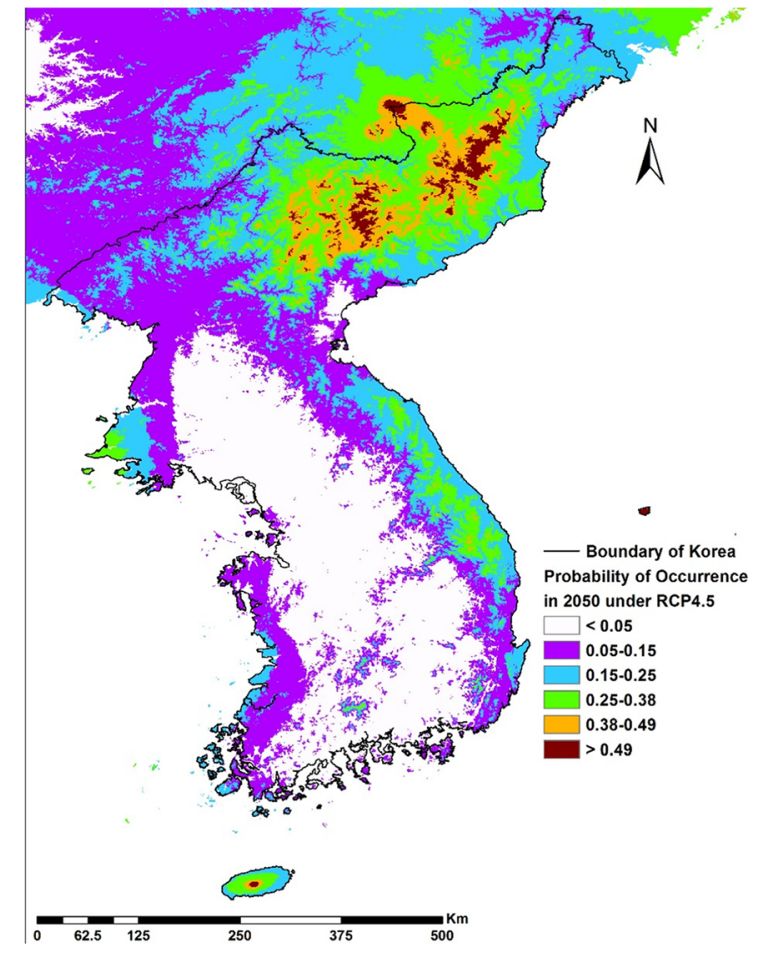

(c)

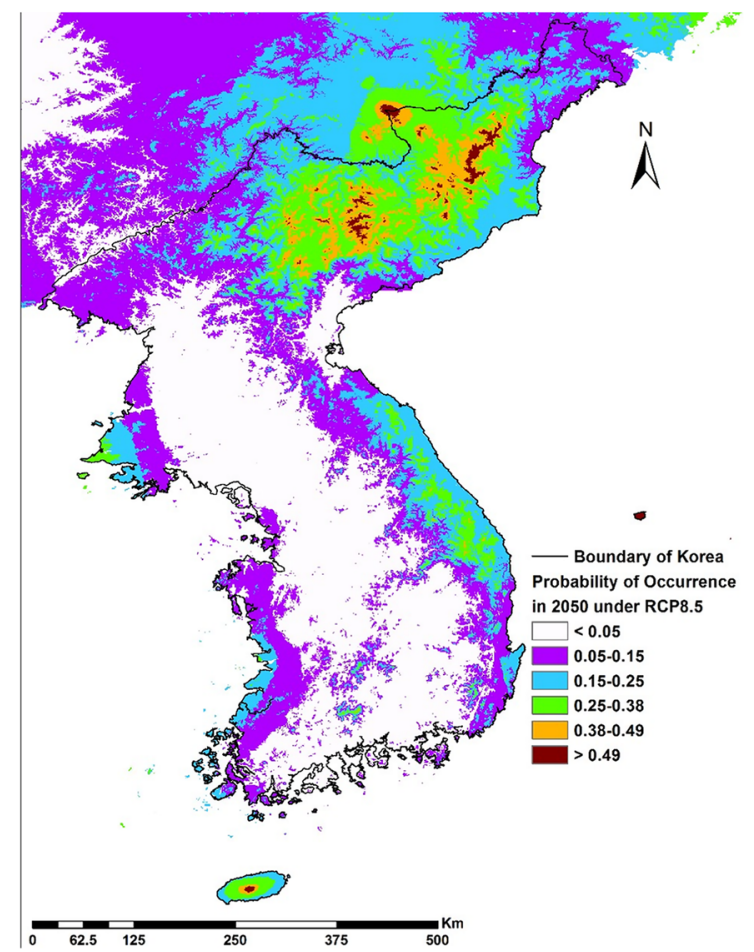

(b)

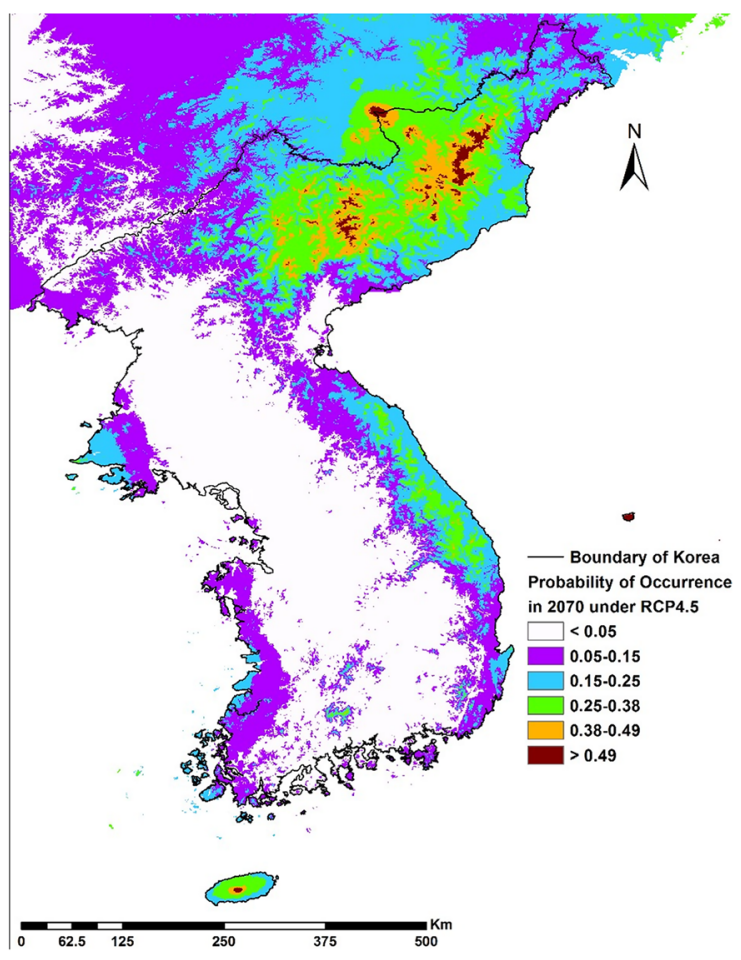

(d)

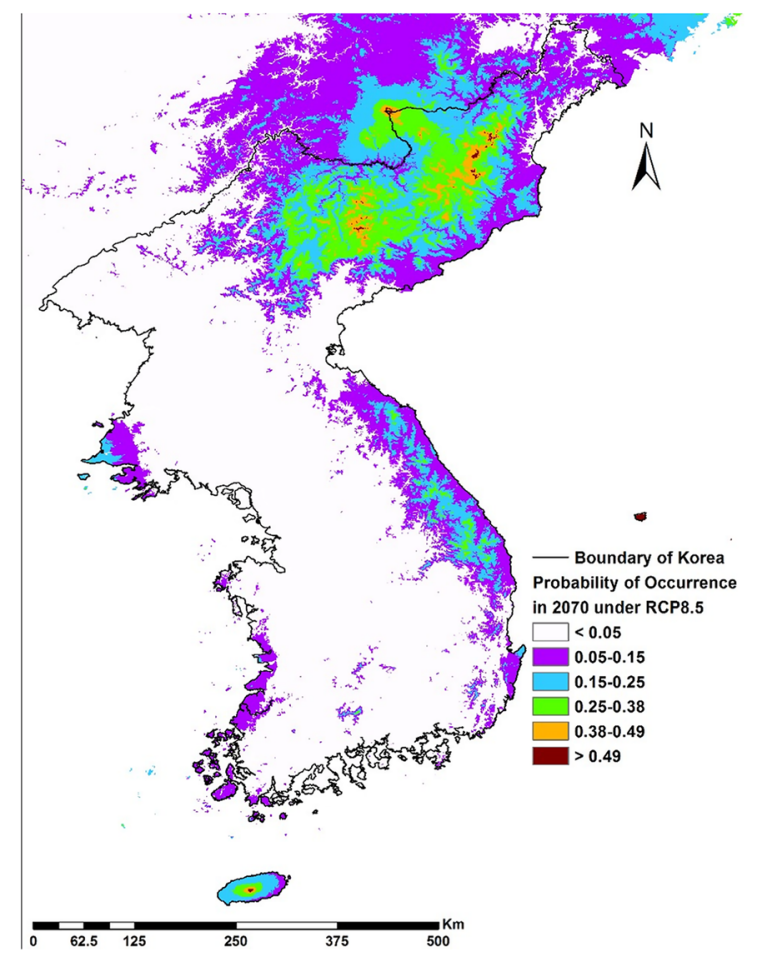

Fig. 1 Prediction of the future habitat suitability for cold-adapted evergreen broadleaf trees under climate change (Koo et al. 2015). The future habitat suitability in 2050 were predicted under RCP4.5 (a) and RCP8.5 (c) and in 2070 under RCP4.5 (b) and RCP8.5 (d) scenarios 
butterfly species and populations was observed at 1665$1700 \mathrm{~m}$ above sea level, indicating that the open grassland space under Baengnokdam is the main habitat for butterflies. By comparing the past monitoring of species such as Hipparchia autonoe, Aphantopus hyperantus, Oeneis urda, and Plebejus argus, which are butterflies living in alpine regions, with the present situation, it was confirmed that the distribution of species is changing from inhabiting alpine regions to inhabiting higher altitude regions, whereas species living in low mountain regions are beginning to be observed in alpine regions.

In addition to temperature increases, habitat is another important variable to consider. Bird species such as Strix uralensis, Dryocopus martius, and Strix aluco favor low temperature conditions; they are now mainly distributed in the continuous forest region of the Baekdudaegan Mountain ranges, which runs from Mt. Soraksan to Mt. Juryman on the Korean peninsula. The change in forest area caused by global warming should be considered when planning management strategies for endangered species living in this environment (Kim et al. 2018b). Park et al. (2018) compared the distribution range of six bird species, namely Pycnonotus sinensis, Sturnus sericeus, Pitta nympha, Hydrophasianus chirurgus, Rostratula benghalensis, and Terpsiphone atrocaudata, between 1997-2005 and 2005-2014; they found that distribution ranges had expanded and moved northward over time. They divided these six species into two categories based on their relationship to climatic factors: climate-change sensitive species (i.e., T. atrocaudata, $H$. chirurgus, and $P$. nympha) and climate-change insensitive species ( $P$. sinensis, $S$. sericeus, and $R$. benghalensis). Climate-change sensitive species are summer migrants; observation records for these species are closely related to temperature data. Distribution range changes include breeding sites moving northward (Choi et al. 2018a). As temperature increases, these species will be found in their main distribution area, such as Jeju-do and southern parts of Korea, as well as the middle and northern areas of Korea. Two opposing estimates have been made for summer migrant birds (e.g., Gallicrex cinerea, Ixobrychus eurhythmus, and $P$. nympha): reduction in their population size due to warming and heat waves but expansion of their distribution range due to breeding success in tropical regions (Park et al. 2018).

Climate-change insensitive species have also expanded their range in Korea. Although observation records for these species are not strongly correlated with temperature, their distribution has expanded in Korea because of reductions in suitable habitats in neighboring China. Two birds, P. sinensis and S. sericeus, are common in urban and rural areas of China. They were first recorded in Korea in the 2000s, but they are now found all over the country where they even breed and overwinter. In this relatively short time span (within 20 years of the first observation record), these birds are now recognized as residents in Korea.

Choi et al. (2018b) monitored the population of two amphibian species, Rana huanrenensis and Hynobius leechi, from 2005 to 2012; they found that the populations had fluctuated over a 3-4-year period and that the population of $H$. leechi had steadily declined. It was revealed that climate change affected the microclimate of this valley habitat, especially by reducing the daily temperature change in spring, which was closely related to the population size of $H$. leechi. The decrease in temperature change in spring would likely increase the energy consumption of $H$. leechi by reducing breeding time, which would in turn continuously reduce the breeding rate of the species and the survival rate after breeding. On the other hand, the decrease in mean annual maximum temperature affected the breeding success and survival rate of $R$. huanrenensis; thus, local microclimate change affected this amphibian species, although the exact mechanism by which the temperature change and population of $R$. huanrenensis were associated is uncertain (Choi et al. 2018b).

Oriental moth species are increasingly being reported in Korea, e.g., a large Uraniid moth, Lyssa zampa, was collected in Seoquipo, Jeu-do (Jeong et al. 2016); three Gelechiid moths previously known to be distributed only in southern China and Taiwan were found in Jeju-do (Kim and Park 2017); and two southern epiplemid moths were also found in the country (Sohn et al. 2019). However, it is unclear whether these species arrived due to global warming or whether they were accidently introduced into Korea.

The following subtropical birds have also been observed in the southern and western islands of Korea: Culicicapa ceylonensis calochrysea (Park and Oh 2018), Cacomantis merulinus querulous (Kim et al. 2018c), and Laysan albatross (Yang et al. 2018). However, it is currently unclear whether this recent increase in subtropical birds in Korea was caused by climate change.

\section{The future direction of biota Phenology}

Climate change effects on flowering time have been predicted for Prunus yedoensis, Pyrus pyrifolia, and Prunus persica (Hur et al. 2014; Hur and Ahn 2015). The flowering timing of $P$. yedoensis is predicted to advance by 6.3 and 11.2 days in 2090 under the RCP 4.5 and RCP 8.5 climate change scenarios, respectively, whereas respective predicted timings for P. pyrifolia are 6.1 and 10.7 days, and those for P. persica are 7.0 and 12.7 days.

To analyze the impact of climate change on forest vegetation, an evaluation index based on satellite images was developed and predictive models were constructed 
(Choi 2015). The correlation between total primary productivity of forests and meteorological factors showed that the growing season was predicted to begin earlier under the RCP 4.5 and 8.5 scenarios. However, total primary production was predicted to decrease, especially in alpine and subalpine regions. These results suggest that the responses of an ecosystem to climate change appear to differ spatially; thus, factors such as climate zone and vegetation should be considered when evaluating the impact of climate change (Table 1).

\section{Diversity and distribution range}

Plants The geographical range of plants and their climate-related range shifts have been investigated for plant species at local and regional scales. Studies have provided range shift predictions under climate change based on the climatically suitable habitat conditions for individual plant species (Shin et al. 2018; Koo et al. 2015; Koo et al. 2016; Park et al. 2016b; Koo et al. 2017a; Koo et al. 2017b; Koo et al. 2017c; Koo et al. 2018; Park et al. 2019) as well as changes in the species composition and diversity of plant communities according to elevational gradient (Kim et al. 2018a; An et al. 2019).

Plant species that are considered vulnerable to climate change were selected from the peaks of Mt. Baekdusan, Mt. Soraksan, Mt. Juryman, and Mt. Hallasan to investigate the impact of global warming on alpine plants (Kong et al. 2014). These vulnerable species were selected based on various factors including species composition, flora, rarity, endemicity, and distribution

Table 1 Future changes of abundance or distribution of species or higher category in Korea

\begin{tabular}{|c|c|c|c|c|}
\hline Change & Kingdom & Organism & Future & Refs. \\
\hline \multirow[t]{9}{*}{ Abundance } & \multirow[t]{3}{*}{ Plants } & Abies koreana, Abies nephrolepis & $\mathrm{D}$ & $\begin{array}{l}\text { Park et al. 2015; Koo et al. } \\
2017 a\end{array}$ \\
\hline & & Abies koreana & I & Koo et al. 2016 \\
\hline & & $\begin{array}{l}\text { Primula farinosa subsp. modesta } \\
\text { Juniperus chinensis var. sargentii }\end{array}$ & $\mathrm{D}$ & Kim et al. 2016a \\
\hline & \multirow[t]{6}{*}{ Animals } & $\begin{array}{l}\text { Aranea (Lycosidae, Ctenidae, Salticidae) } \\
\text { Crustacea } \\
\text { Oniscomorphia } \\
\text { Gryllidae } \\
\text { Hemiptera } \\
\text { Diptera (Dolichopodidae) } \\
\text { Coleoptera (Scarabaeidae) }\end{array}$ & I & \multirow[t]{2}{*}{ Lee et al. 2016} \\
\hline & & $\begin{array}{l}\text { Aranea (Theridiidae, Linyphiidae, Agelenidae, Hahniidae, Clubionidae, Gnaphosidae, } \\
\text { Thomisidae) } \\
\text { Juliformia } \\
\text { Archaeognatha } \\
\text { Homoptera } \\
\text { Formicidae (Hymenoptera) } \\
\text { Diptera } \\
\text { Lepidoptera } \\
\text { Coleoptera (Hydrophilidae, Silphidae, Melolonthidae, Elateridae, Tenebrionidae, } \\
\text { Curculionidae) } \\
\text { Diptera (Anisopodidae) }\end{array}$ & $\mathrm{D}$ & \\
\hline & & $\begin{array}{l}\text { Ephemeroptera, } \\
\text { Plecoptera, } \\
\text { Trichoptera }\end{array}$ & $\mathrm{D}$ & \multirow[t]{2}{*}{ Li et al. 2013; Li et al. 2014} \\
\hline & & Odonata & 1 & \\
\hline & & $\begin{array}{l}\text { Cervus nippon, Moschus moschiferus, Plecotus ognevi, Hyla suweonensis, Acoptolabrus } \\
\text { mirabilissimus mirabilissimus, Lethocerus deyrolli, Parnassius bremeri }\end{array}$ & $\mathrm{D}$ & \multirow[t]{2}{*}{ Kim et al. 2018b } \\
\hline & & $\begin{array}{l}\text { Pteromys volans, Strix uralensis, Dryocopus martius, Strix aluco, Gallicrex cinerea, } \\
\text { Ixobrychus eurhythmus, and Pitta nympha }\end{array}$ & $\mathrm{D}$ & \\
\hline \multirow[t]{4}{*}{ Distribution } & \multirow[t]{2}{*}{ Plants } & $\begin{array}{l}\text { Machilus thunbergii, Castanopsis cuspidate, Pittosporum tobira, Raphiolepis indica var. } \\
\text { umbellata, Eurya emarginata, Hedera japonica }\end{array}$ & $E$ & $\begin{array}{l}\text { Park et al. 2016b: Koo et al. } \\
\text { 2017b: Koo et al. } 2017 c\end{array}$ \\
\hline & & $\begin{array}{l}\text { Kadsura japonica, Neolitsea sericea, llex integra, } \\
\text { Dendropanax morbifera }\end{array}$ & $S$ & $\begin{array}{l}\text { Koo et al. 2017c: Koo et al. } \\
2018\end{array}$ \\
\hline & \multirow[t]{2}{*}{ Animals } & Ursus thibetanus ussuricus & $\mathrm{E}$ & Kim et al. 2016a, b, c \\
\hline & & Sibynophis chinensis & $\mathrm{E}$ & Koo et al. 2019 \\
\hline
\end{tabular}


pattern. Although the future ranges of cold-adapted plants, i.e., those distributed in high mountainous areas such as alpine and subalpine belts, were mostly predicted to shrink and shift to northern and high-elevation areas (Koo et al. 2015; Koo et al. 2017a), the ranges of warm-adapted plants, i.e., those that inhabit low land areas, were mostly predicted to expand and shift to northern areas (Park et al. 2016a, 2016b; Koo et al. 2017b; Park et al. 2019). However, the level of change in future ranges was species-specific, suggesting the need for species-specific predictions and management practices (Koo et al. 2016).

Populations of Abies koreana and Abies nephrolepis, which are cold-adapted subalpine fir species in Korea, were predicted to decrease under climate change at a local scale (Mt. Hallasan) and national scale (Fig. 2; Park et al. 2015; Koo et al. 2017a). However, one study suggested that increased precipitation would possibly increase the climatically suitable habitats of $A$. koreana under the RCP 4.5 and 8.0 scenarios predicted by the

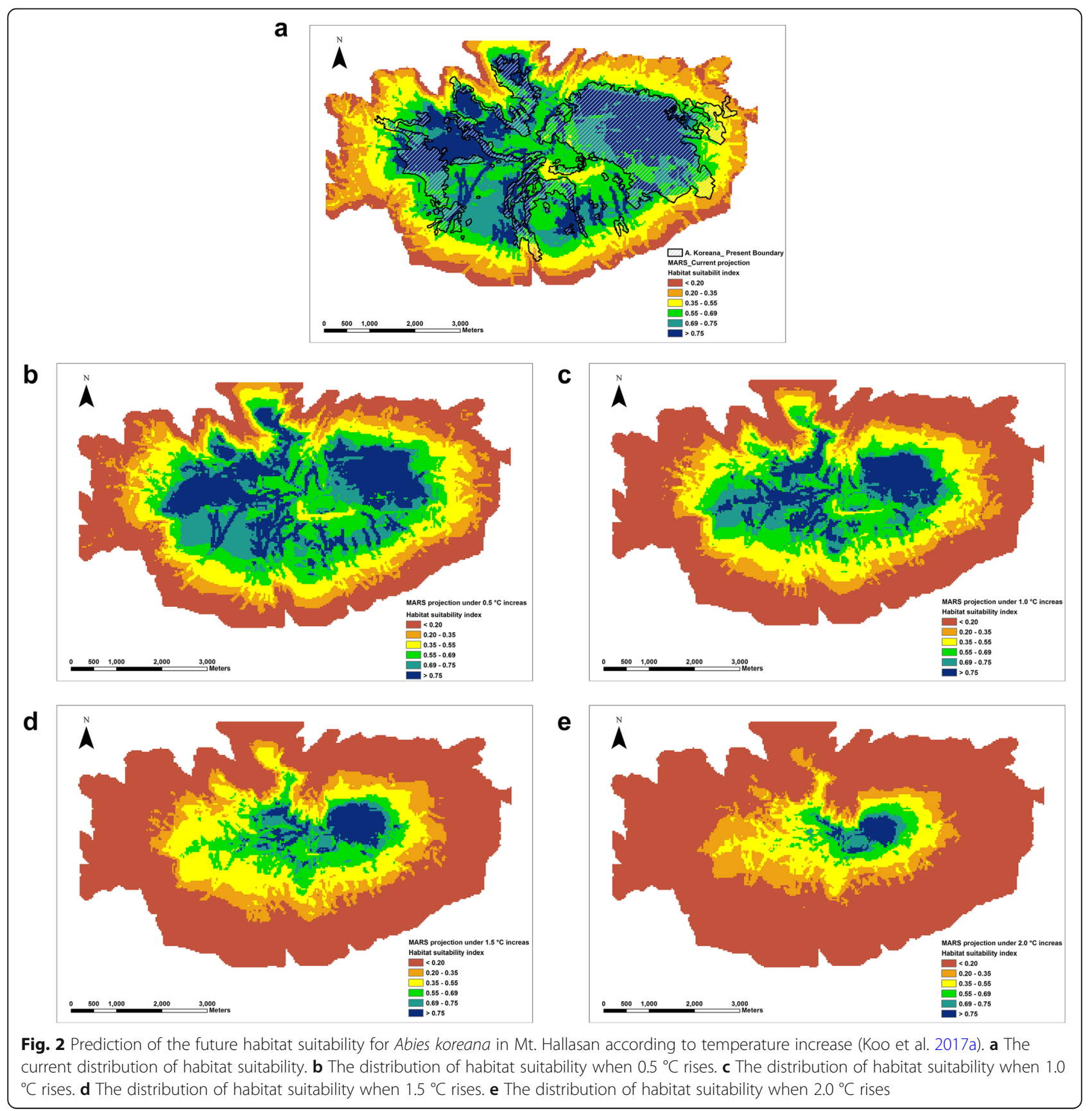


general circulation model (GCM) of the Hadley Center, UK (Koo et al. 2016; Koo et al. 2017c; Koo et al. 2018). Assessment of flora on some islands on the southern coast of Jeollanam-do (Kim et al. 2016a) showed that the ranges of species that prefer cool climates, e.g., Primula farinosa subsp. modesta, and Juniperus chinensis var. sargentii, could rapidly decrease under climate change conditions. In addition, 69\% species inhabited fewer than seven islands with $\sim 25 \%$ species found on one island, which highlights the biogeographical importance of the southern coastal islands. Most islands have a unique ecosystem due to their geographical isolation and narrow area; hence, they may be particularly vulnerable to rapid climate change.

Changes in the ranges of warm-adapted broad-leaved plants were species-specific (Park et al. 2016a, 2016b). The future ranges of Machilus thunbergii, Castanopsis cuspidata, Pittosporum tobira, Raphiolepis indica var. umbellate, Eurya emarginata, and Hedera japonica, which currently have wide ranges, were predicted to expand further under climate change (Park et al. 2016b; Koo et al. 2017b). However, species such as Kadsura japonica, Neolitsea sericea, Ilex integra, and Dendropanax morbifera with narrow current ranges, i.e., those distributed only in specific areas such as the coast, were predicted to lose their habitats (Koo et al. 2017c; Koo et al. 2018). In addition, when adaptation capacity, such as dispersal capacity, was considered, the degree of expansion decreased (Park et al. 2017; Park et al. 2019).

Animals Lee et al. (2016) modeled the changes of diversity and abundance of arthropods from 2056 to 2065 using the RCP 4.5 and RCP 8.5 scenarios in Korea. They concluded that diversity and abundance would decrease by $13-36 \%$ and $5-13 \%$, respectively as global temperature increased. Lee et al. $(2015 a, 2016)$ estimated the changes at higher taxonomic levels such as family or order and found no consistent pattern across all arthropods (Table 1 ).

Among dipterans, the Anisopodidae would decrease substantially under climate change. They are detritivores or fungi-feeders living in humid forests; they are currently found in Gangwon province but will disappear within 50 years. Numbers of Anisopodidae are closely related to climatic factors: negatively with temperature and positively with precipitation. Dolichopodidae, small predatory flies living in open habitats, would increase in number by $17.5-54.3 \%$; their abundance is closely associated with the minimum temperature. Currently, Dolichopodidae are common in Gyungnam Province, but they will spread to southern areas in 50 years.

Kwon et al. (2014b), Kwon and Lee (2015), and Kwon et al. (2015) estimated changes in the abundance of spiders (Kwon et al. 2014b), ants (Kwon and Lee 2015), and beetles (Kwon et al. 2015); they found that the numbers of species with decreasing abundance (69 spider, 32 ant, and 77 beetle species) would be higher than those of species with increasing abundance ( 9 spider, 15 ant, and 57 beetle species) as temperature increases. In particular, ants were affected by maximum and average temperatures (Kwon et al. 2015).

Distribution of aquatic insects such as Ephemeroptera, Odonata, Plecoptera, and Trichoptera were examined to estimate future distribution in 501 study sites across Korea ( $\mathrm{Li}$ et al. 2013; $\mathrm{Li}$ et al. 2014). In these studies, most aquatic insects, except Odonata, would be decreasing in abundance continuously by the 2040s and be extinct by the 2060s. In high mountain streams, biodiversity will be decreased by the extinction of $20 \%$ of species by the 2080s ( $\mathrm{Li}$ et al. 2013). Plecoptera would be most severely affected $(62.1 \%$ decrease $)$ relative to Trichoptera (17.8\%) and Ephemeroptera (15.2\%). As temperature increases, aquatic insects that favor low temperatures will move to higher elevations or latitudes. Plecopterans will be most vulnerable since their flight ability was at $<60 \mathrm{~m}$, whereas dragonfly numbers will increase as temperature increases (Table 1).

Analysis of species composition by elevation showed that species were likely to be more similar in the future (Li et al. 2014). The distribution of fish species in the Geum River basin according to climate change was predicted using the MaxEnt model (Bae and Jung 2015). The distribution of fish species in 2050 and 2100 was predicted assuming the RCP 8.5 scenario and variables including water depth, precipitation, and minimum water temperature strongly contributed to these predictions. In addition, regions with high species abundance in the watershed moved north, while some fishes were expected to disappear in the Geum River watershed by 2100 , confirming that climate change could greatly disturb this aquatic ecosystem. The streams are ecologically and biologically similar in their characteristics, but the organisms living in this ecosystem will adapt differently because of species-specific characteristics.

\section{Species of great concern (current and future directions) Endangered species}

Plants that are endangered by climate change were identified at Mt. Gayasan (Kim et al. 2017b) and classified into three types: lowland, subalpine, and widespread distribution. Lowland and widespread species are predicted to be relatively less affected by global warming or to expand their vertical distribution, whereas subalpine types are expected to be sensitive to climate change due to their narrow distribution range and small population sizes.

Seven endangered animal species, three mammals (Cervus nippon, Moschus moschiferus, and Plecotus ognevi), 
one amphibian (Hyla suweonensis), and three insects (Acoptolabrus mirabilissimus mirabilissimus, Lethocerus deyrolli, and Parnassius bremeri), are vulnerable to climate change mainly due to their adaptations to low temperature and narrow distribution.

Endangered species with narrow distribution ranges are generally predicted to be more susceptible to climate change. Kim et al. (2018b) examined the change in distribution of endangered species after climate change using the RCP 4.5 and 8.5 scenarios; they found that species such as Pteromys volans, Strix uralensis, Dryocopus martius, Strix aluco, Gallicrex cinerea, Ixobrychus eurhythmus, and P. nympha will be vulnerable in the 2070s. Kim et al. (2016b) also estimated the distribution of another endangered species, Ursus thibetanus ussuricus, after climate change; forest cover and precipitation were found to be more important to the distribution of $U$. thibetanus than temperature. In future, the distribution range of this species could be increased 10 -fold by 2050 and 15 -fold by 2070 .

Koo et al. (2019) investigated the habitat requirements of an endemic species, Sibynophis chinensis, and predicted its future distribution range. This species is currently protected under endangered species regulation and law because it is endemic in Jejdu-do, whereas other species are widely distributed in Southeast Asia including China, Hong Kong, and Vietnam. Precipitation during the monsoon season was the major variable for the distribution of $S$. chinensis and its future distribution range could differ depending on the area: it might decrease in the western and high mountain region while increasing in the eastern part of the island.

\section{Invasive and pest species}

The climate-related range shifts of invasive plant species, Paspalum distichum var. indutum, Conyza bonariensis, and Amaranthus viridis, were predicted for management (Cho and Lee 2015; Lee et al. 2015b, 2016). The potential distribution of $A$. viridis was predicted to increase of $110 \%$ under RCP 4.5 and $470 \%$ under RCP 8.5 in 2090 (Lee et al. 2016). The range of $P$. distichum var. indutum was predicted to expand further inland and shift to northern areas (Cho and Lee 2015). The potential distribution of C. bonariensis was predicted to increase of $338 \%$ under RCP 4.5 and $769 \%$ under RCP 8.5 in 2100s (Lee et al. 2015b).

The distributions of disease vectors, such as mosquitoes and mites, could change in the Korean peninsula because of climate change given the changes to warming and wetness. Lee et al. (2017) estimated that insect disease vectors could move northward due to global warming. For example, the Asian tiger mosquito Stegomyia albopicta, a vector of Dengue fever and Zika virus, could be found in Korea when the mean winter temperature is
$>10{ }^{\circ} \mathrm{C}$ in the 2050s. Vectors of scrub typhus, namely Leptotrombidium pallidum and Leptotrombidium scutellare, are currently distributed in different parts of Korea: L. pallidum in the midlands and L. scutellare in the southern parts including Jeju-do Island.

The Asian hornet, Vespa velutina nigrithorax, is an invasive wasp species that has widened its distribution range since 2003. It was first found in Busan in 2003 and gradually expanded to other parts of Korea: 103 counties in 2014 and 155 counties in 2015. This spread was the result of climatic factors such as a shortened monsoon period and increased summer temperature, which increased the rate of overwintering and the number of honeybee colonies (Park and Jung 2016). In the RCP 8.5 scenario, the potential distribution of the Asian hornet could cover the entire country and this expansion would change the wasp community by transforming species interactions among wasp species (Park and Jung 2016).

Another invasive pest species, the brown winged cicada Pochazia shantungensis, has severely affected trees in orchards and on roadsides since 2010. This species of Chinese origin was first found in midwest Korea, for example Gongju and Yesan, Chungchungnam-do (Kim et al. 2015b). Environmental factors for the distribution of this species were mainly climatic factors, i.e., precipitation and mean temperature during the summer, with forest cover and plant species type being the other factors. Based on the current distribution of P. shantungensis, its range could be confined to the midwest region, i.e., 34\% of the total area of Korea. However, its host plants comprise $>138$ species including deciduous, coniferous, and grass varieties. Thus, its wide range of host plants may accelerate the spread of this pest species in the near future.

It has been shown that temperature increase can control the development rate of some insects that are susceptible to high temperatures. Kim et al. (2016c) investigated the cause of changes in the seasonal occurrence of two moth species, Plutella xylostella and Spodoptera exigua, both of which are major cabbage pest species by considering high-temperature susceptibility above $40{ }^{\circ} \mathrm{C}$. They found that $P$. xylostella was more sensitive than $S$. exigua to high temperature because heatshock protein coding genes such as Hsp70, Hsp74, and Hsp83 in P. xylostella were translated into proteins involved in the control of temperature stress and the synthesis of glycerol (i.e., blood sugar). However, global warming could affect populations of pest species whether or not they have physiological mechanisms to protect against temperature change.

\section{Conclusion}

Throughout the present review, we observed that plants and animals in Korea face climate change by extending 
or shifting their ranges toward the north and populations have been migrating, developing, or reproducing earlier than their previous growing or breeding time. This will bring asynchronies in food web and this eventually increases species and ecosystem vulnerability. About $20-30 \%$ of the plant and animal species including species that are climate sensitive and/or are adapted to alpine or subalpine habitats are at risk of extinction in the end of this century (Settele et al. 2015). Climate change is ongoing and this change coupled with human disturbances has led to biodiversity loss and ecosystem degradation. Korea is not an exception. The continuous monitoring of ecosystem change to track phenology, population fluctuation, and pest outbreak should be implemented at the local, regional, national, and global scales, and the appropriate conservation management and practices at the genetic and population levels also should be followed.

\section{Abbreviations}

DPRK: The Democratic People's Republic of Korea (DPRK); Hsp70: Heat shock proteins 70; Hsp74: Heat shock 70 kDa protein 4; Hsp83: Heat shock proteins 83; KCCAR: Korean Climate Change Assessment Report 2020; Köppen climate zone of Cwa: The dry-winter humid subtropical climate; Köppen climate zone of Cfa: The humid subtropical climate zone; RCP: Representative concentration pathway; ROK: The Republic of Korea

\section{Acknowledgements}

Not applicable.

\section{Authors' contributions}

SWC and KAK conceived the study and designed the manuscript. SWC reviewed and wrote the animal ecology part of the manuscript, KAK plant ecology, and WSK and GYH vulnerable ecosystem. WSK and GYH gave conceptual advices and edited the manuscript. The author(s) read and approved the final manuscript.

\section{Funding}

This research was supported by the research project "Developing climate change adaptation DB.Inventory and grid-based spatialization techniques for supporting adaptation decision-making in local government" (2020-005), which was conducted by the Korea Environment Institute (KEI) and funded by Korea Environment Industry \& Technology Institute (KEITI) through Climate Change Correspondence Program (Project No. 2018001310004) of the Korea Ministry of Environment and also supported by the research project "A Study on Development of Integrated System for National Biodiversity Strategies and Action Plan (NBSAP)-Indicator-Implementation AssessmentEffectiveness Assessment" (RE2021-13), funded by the Korea Environment Institute (KEI).

\section{Availability of data and materials}

The datasets used and/or analyzed during the current study are available from the corresponding author on reasonable request.

\section{Declarations}

Ethics approval and consent to participate

Not applicable.

\section{Consent for publication}

Not applicable.

\section{Competing interests}

The authors declare that they have no competing interests.

\section{Author details}

${ }^{1}$ Department of Environmental Education, Mokpo National University, Muan, Jeonnam 58554, Republic of Korea. ²Department of Geography, Kyung Hee University, Seoul 02447, Republic of Korea. ${ }^{3}$ Gangwon Regional Headquarter, Korea Rural Community Corporation, Chuncheon, Gangwon 24226, Republic of Korea. ${ }^{4}$ Division for Natural Environment, Water and Land Research Group, Korea Environment Institute, Sejong 30147, Republic of Korea.

Received: 25 May 2021 Accepted: 14 July 2021

Published online: 10 August 2021

\section{References}

Ahn $\mathrm{KH}$, You YH, Cho KT. Growth response to light, moisture and nutrients for the conservation measures of Bupleurum latissimum (Apiaceae, endangered species) under future climate environment (Elevated CO 2 concentration and temperature). Korean J Environ Ecol. 2016;30(5):803-9. https://doi.org/10.1304 7/KJEE.2016.30.5.803.

An JH, Park HJ, Lee SR, Seo IS, Nam GH, Kim JH. Analysis of environmental factors and change of vascular plant species along an elevational gradients in Baekdansa, Mt. Taebaeksan National Park. Korean J Environ Ecol. 2019;33(4): 378-401. https://doi.org/10.13047/KJEE.2019.33.4.378.

Bae EH, Jung JH. Prediction of shift in fish distributions in the Geum River watershed under climate change. Ecol Resilient Infrastructure. 2015;2(3):198205. https://doi.org/10.17820/eri.2015.2.3.198.

Bae YJ, Lee HJ, Jung BW, Jung HC. Korean Climate Change Assessment Report 2020 - Climate Impact and Adaptation. Sejong: Ministry of Environment, Korean Government; 2020.

Cho $\mathrm{KH}$, Lee SH. Prediction of changes in the potential distribution of a waterfront alien plant, Paspalum distichum var. indutum, under climate change in the Korean Peninsula. Ecol Resilient Infrastructure. 2015;2(3):20615. https://doi.org/10.17820/eri.2015.2.3.206.

Choi $\mathrm{CH}$. Climate change impact assessment and predictive model on forest ecology using MODIS [Dissertation]. Daegu: Kyungpook National University; 2015. p. 232.

Choi CH, Jung SG, Park KH. Analyzing relationship between satellite-based plant phenology and temperature. J Korean Assoc Geogr Inf Stud. 2016;19(1):3042. https://doi.org/10.11108/kagis.2016.19.1.030.

Choi GY. Projections of changing temperature and climate zones over Mt. Halla, Korea using high resolution climate change scenario data. J Climate Res. 2017;12(3):243-57. https://doi.org/10.14383/cri.2017.12.3.243.

Choi HJ, Park SY. Policy and implications for response to climate change in island coast regions. J Water Policy Econ. 2018;30:79-92.

Choi SK, Lim SJ, Park YC. Environmental factors affecting habitat selection of the endangered Japanese paradise flycatcher (Terpsiphone atrocaudata). J Agric Life Sci. 2018a;52(1):45-52. https://doi.org/10.14397/jals.2018.52.1.45.

Choi WJ, Park D, Kim JK, Lee JH, Kim DI, Kim IH. Changes in the reproductive population size of the Huanren brown frog (Rana huanrenensis) and Wonsan salamander (Hynobius leechii), which breeding in mountain valleys, according to climate change. Korean J Environ Ecol. 2018b;32(6):582-90. https://doi. org/10.13047/KJEE.2018.32.6.582.

Chung YS, Yoon MB, Kim HS. On climate variations and changes observed in South Korea. Clim Change. 2004;66(1-2):151-61. https://doi.org/10.1023/B: CLIM.0000043141.54763.f8.

Hur J, Ahn JB. The change of first-flowering date over South Korea projected from downscaled IPCC AR5 simulation: peach and pear. Int J Climatol. 2015; 35(8):1926-37. https://doi.org/10.1002/joc.4098.

Hur J, Ahn JB, Shim KM. The change of cherry first-flowering date over South Korea projected from downscaled IPCC AR5 simulation. Int I Climatol. 2014; 34(7):2308-19. https://doi.org/10.1002/joc.3839.

Jang DH, Kim SH. Vulnerability assessment on climate change for mountainous wetland in Shinbul Mountain using multi-temporal aerial photograph and climate data. J Assoc Korean Photo-Geographers. 2013;23(1):39-52. https:// doi.org/10.35149/jakpg.2013.23.1.004.

Jang W, Keyes CR, Running SW, Lim JH, Park PS. Climate-growth relationships of relict Picea jezoensis at Mt. Gyebang, South Korea. Forest Sci Technol. 2015; 11(1):19-26.

Jeong HC, Kim MJ, Kim I, Choi SW. A new record of Lyssa zampa (Butler) from Korea. J Species Res. 2016;5(2):220-2. https://doi.org/10.12651/JSR.2 016.5.2.220.

Jung HS, Choi Y, Oh JH, Lim JH. Recent trends in temperature and precipitation over south Korea. Int J Climatol. 2004;22:1327-37. 
Jung MP, Shim KM, Kim Y, Choi IT. Change of climatic growing season in Korea. Korean J Environm Agric. 2015;34(3):192-5. https://doi.org/10.5338/KJEA.201 5.34.3.27.

Jung MP, Shim KM, Kim YS, Choi IT, So KH. Trend of climatic growing season using average daily temperature (1971-2013) in Suwon Korea. J Climate Change Res. 2014;5(4):285-9. https://doi.org/10.15531/ksccr.2014.5.4.285.

Kim CC, Kim TG. Evaluation on climate change vulnerability of Korea National Parks. Korean J Ecol Environ. 2016;49(1):42-50. https://doi.org/10.11614/KSL.2 016.49.1.042.

Kim DE, Lee H, Kim MJ, Lee DH. Predicting the potential habitat, host plants, and geographical distribution of Pochazia shantungensis (Hemiptera: Ricaniidae) in Korea. Korean J Appl Entomol. 2015b;54(3):179-89. https://doi.org/10.5656/ KSAE.2015.06.0.011.

Kim DS, Park SJ, Kim DS, Cho YB, Lee YD, Ahn NH, et al. Monitoring of the butterfly communities inhabited of Mt. Hallasan, Jeju Island, Korea. Korean J Environ Ecol. 2014;28(6):697-704. https://doi.org/10.13047/KJEE.2014.28.6.697.

Kim ES, Cho HB, Heo D, Kim NS, Kim YS, Lee K, et al. Precision monitoring of radial growth of trees and micro-climate at a Korean Fir (Abies koreana Wilson) forest at 10 minutes interval in 2016 on Mt. Hallasan National Park, Jeju Island, Korea. Korean J Ecol Environ. 2019b;43(1):1-20.

Kim ES, Lee JS, Park GE, Lim JH. Change of subalpine coniferous forest area over the last 20 Years. J Korean Soc Forest Sci. 2019a;1:10-20.

Kim H, Kim HJ, Park JY. A new record of Plaintive Cuckoo (Cacomantis merulinus) in Korea. Korean J Ornithol. 2018c;25(2):133-5. https://doi.org/10.30980/KJO.2 018.12.25.2.133.

Kim HH, Kim DB, Won HK, Kim CS, Kong WS. Island-Biogeographical Characteristics of Insular Flora in Southern Sea of Jeollanamdo. Korea J Climate Change Res. 2016a;7(2):143-55. https://doi.org/10.15531/ksccr.2016. 7.2.143.

Kim HS, Myeong HH. 2014: Changes in the environmental factors of halophyte habitat in Suncheon Bay. J Korean Island. 2014;26(4):195-211.

Kim JD, Park GE, Lim JH, Yun CW. Vegetation type classification and endemic-rare plants investigation in forest vegetation area distributed by vulnerable species to climate Change, Mt. Jiri. J Korean Soc Forest Sci. 2018a;107(2):113-25.

Kim JE, Youn YT, Jo KS, Moon JY. Korea climate change and characteristic. Korean J Meteorological Soc. 2007;10:472-3.

Kim JY, Hong SB, Shin MS. Analysis of sensitivity and vulnerability of endangered wild animals to global warming. J Climate Change Res. 2018b;9(3):235-43. https://doi.org/10.15531/KSCCR.2018.9.3.235.

Kim M, Lee S, Kim Y. Differential susceptibility to high temperature and variation of seasonal occurrence between Spodoptera exigua and Plutella xylostella. Korean J Appl Entomol. 2016c;55(1):17-26.

Kim M, Park KT. Three species of Gelechiidae (Lepidoptera: Gelechioidea) new to Korea. Korean J Appl Entomol. 2017:56(1):93-6.

Kim R, Yu D, Choi H. A phytogeographical study of Sasa borealis populations based on AFLP analysis. Korean J Plant Taxonomy. 2015a;45(1):29-35. https:// doi.org/10.11110/kjpt.2015.45.1.29

Kim TG, Yang D, Cho Y, Song KH, Oh JG. Habitat distribution change prediction of Asiatic black bears (Ursus thibetanus) using Maxent modeling approach. Korean J Ecol Environ. 2016b;49(3):197-207. https://doi.org/10.11614/KSL.201 6.49.3.197.

Kim YS, Shim KM, Jung MP, Choi IT, Kang KK. Study on the change of climate zone in South Korea by the climate change scenarios. Korean J Agric Forest Meteorol. 2017a;19(2):37-42

Kim YY, Leem HS, Han HS, Ji SJ, So SK. Conservation measures and distribution of vulnerable species climate change in Gayasan National Park. Korean J Plant Res. 2017b;30(2):167-75. https://doi.org/10.7732/kjpr.2017.30.2.167.

Kong WS, Kim KO, Lee SG, Park HN, Cho SH. Distribution of high mountain plants and species vulnerability against climate change. J Environ Impact Assess. 2014;23(2):119-36. https://doi.org/10.14249/eia.2014.23.2.119.

Koo KA, Kim JU, Kong WS, Jung HC, Kim GH. Projecting the potential distribution of Abies koreana in Korea under the climate change based on RCP scenarios. J Korean Environ Res Technol. 2016;19(6):19-30.

Koo KA, Kong WS, Nibbelink NP, Hopkinson CS, Lee JH. Potential effects of climate change on the distribution of cold-tolerant evergreen broadleaved woody plants in the Korean Peninsula. PLoS One. 2015;10(8):e0134043. https://doi.org/10.1371/journal.pone.0134043.

Koo KA, Kong WS, Park SU, Lee JH, Kim J, Jung H. Sensitivity of Korean fir (Abies koreana Wils.), a threatened climate relict species, to increasing temperature at an island subalpine area. Ecol Model. 2017a;353:5-16. https://doi.org/10.1 016/j.ecolmodel.2017.01.018.
Koo KA, Park SU, Hong S, Jang I, Seo C. Future distributions of warm-adapted evergreen trees, Neolitsea sericea and Camellia japonica under climate change: ensemble forecasts and predictive uncertainty. Ecol Res. 2018;33(2): 313-25. https://doi.org/10.1007/s11284-017-1535-3.

Koo KA, Park SU, Kong WS, Hong S, Jang I, Seo C. Potential climate change effects on tree distributions in the Korean Peninsula: Understanding model \& climate uncertainties. Ecol Model. 2017b;353:17-27. https://doi.org/10.1016/j. ecolmodel.2016.10.007.

Koo KA, Park SU, Seo C. Effects of climate change on the climatic niches of warm-adapted evergreen plants: expansion or contraction? Forests. 2017C; 8(12):500. https://doi.org/10.3390/f8120500.

Koo KS, Park D, Oh HS. Analyzing habitat characteristics and predicting present and future suitable habitats of Sibynophis chinensis based on a climate change scenario. J Asia-Pac Biodivers. 2019;12(1):1-6. https://doi.org/10.1016/ j.japb.2018.11.001.

Korea Meteorological Administration (KMA). Summary of Korea Global Atmosphere Watch 2011 Report. KMA. 2012;201:10.

Kwon TS, Lee CM. Prediction of abundance of ants according to climate change scenarios RCP 4.5 and 8.5 in South Korea. Jour. Asia-Pac Biodivers. 2015;8(1): 49-65. https://doi.org/10.1016/j.japb.2015.01.003.

Kwon TS, Lee CM, Kim SS. Northward range shifts in Korean butterflies. Clim Change. 2014a;126(1-2):163-74. https://doi.org/10.1007/s10584-014-1212-2.

Kwon TS, Lee CM, Kim SS. Prediction of abundance of beetles according to climate warming in South Korea. J Asia-Pac Biodivers. 2015;8(1):7-30. https:// doi.org/10.1016/j.japb.2015.01.001.

Kwon TS, Lee CM, Kim TW, Kim SS, Sung JH. Prediction of abundance of forest spiders according to climate warming in South Korea. J Asia-Pac Biodivers. 2014b;7:133-55.

Lee CM, Kwon TS, Ji OY, Kim S, Park GE, Lim JH. Prediction of abundance of forest flies (Diptera) according to climate scenarios RCP 4.5 and RCP 8.5 in South Korea. J Asia-Pac Biodivers. 2015a;8(4):349-70. https://doi.org/10.1016/j. japb.2015.10.009.

Lee JS, Lee KT, Kim CK, Park GH, Lee JH, Park YG, et al. Influence of the increase of dissolved $\mathrm{CO}_{2}$ concentration on the marine organisms and ecosystems. J Korean Soc Mar Environ Eng. 2006;9(4):243-52.

Lee SI, Lee EP, Jung YH, Kim EJ, Lee JK, Lee SY, et al. Study of ecological response of endangered Sarcandra glabra (Thunb.) Nakai according to moisture and nutrient under condition of climate change for propagation and restoration. Korean J Environ Ecol. 2018;32(1):30-8. https://doi.org/10.13047/KJEE.201 8.32.1.30.

Lee $\mathrm{YH}$, Hong SH, Na CS, Sohn Sl, Kim MH, Kim CS, et al. Predicting the suitable habitat of Amaranthus viridis based on climate change scenarios by MaxEnt. Korean J Environ Biol. 2016;34(4):240-5. https://doi.org/10.11626/KJEB.201 6.34.4.240.

Lee YH, Oh YJ, Hong SH, Na CS, Na YE, Kim CS, et al. Predicting the suitable habitat of invasive alien plant Conyza bonariensis based on climate change scenarios. J Climate Change Res. 2015b;6(3):243-8. https://doi.org/10.15531/ ksccr.2015.6.3.243.

Lee YJ, Kim KS, Cho JG. Distribution of epilithic diatom assemblages in an urban stream in Busan: effected of urban climatic conditions. Korean J Environ Biol. 2017;35(2):143-51. https://doi.org/10.11626/KJEB.2017.35.2.143.

Li F, Chung N, Bae MJ, Kwon YS, Kwon TS, Park YS. Temperature change and macro-invertebrate biodiversity: assessments of organism vulnerability and potential distributions. Clim Change. 2013;9:421-34.

Li F, Kwon YS, Bae MJ, Chung N, Kwon TS, Park YS. Potential impacts of global warming on the diversity and distribution of stream insects in South Korea. Conserv Biol. 2014;8:498-508.

Moon BR, Kim DM, Lee SM. A prediction on the wetlands change of Suncheon Bay by the sea level rise. J Fisheries Mar Sci Educ. 2017;29(3):627-35. https:// doi.org/10.13000/JFMSE.2017.29.3.627.

National Institute of Meteorological Sciences (NIMS). Climate Change of the Korean Peninsula for Last 100 Years. Jejudo: NIMS; 2018. p. 31.

Park H, Lee J, Lee G, Um G. Environmental features of the distribution areas and climate sensitivity assessment of Korean Fir and Khinghan Fir. J Environ Impact Assess. 2015;24(3):260-77. https://doi.org/10.14249/eia.2015.24.3.260.

Park H, Park DY, Choi SK. Changes in avian distribution in the Republic of Korea a response to climatic and environmental condition change. J Energy Climate Change Educ. 2018;8(2):235-53.

Park JJ, Jung C. Risk prediction of the distribution of invasive hornet, Vespa velutina nigrothorax in Korea using CLIMEX model. Korean J Apiculture. 2016; 31(4):293-303. https://doi.org/10.17519/apiculture.2016.11.31.4.293. 
Park JY, Oh MR. First record of Grey-headed Canary Flycatcher (Culicicapa ceylonensis). in Korea. Korean J Ornithol. 2018;25:62-4.

Park SU, Koo KA, Kong WS. Potential impact of climate change on distribution of warm temperate evergreen broad-leaved trees in the Korean Peninsula. J Korean Geogr Soc. 2016a;51(2):201-17.

Park SU, Koo KA, Kong WS. Climate-related range shifts of climate-sensitive biological indicator species in the Korean Peninsula: A Role of dispersal capacity. J Climate Change Res. 2019;10(3):185-98. https://doi.org/10.15531/ KSCCR.2019.10.3.185.

Park SU, Koo KA, Seo C, Hong S. Climate-related range shifts of Ardisia japonica in the Korean Peninsula: a role of dispersal capacity. J Ecol Environ. 2017:41(1):1-8.

Park SU, Koo KA, Seo C, Kong WS. Potential impact of climate change on distribution of Hedera rhombea in the Korean Peninsula. J Climate Change Res. 2016b;7(3):325-34. https://doi.org/10.15531/ksccr.2016.7.3.325.

Seo JW, Jeong HM, Lee KH, Park HC. Dating the dead years of Korean fir (Abies koreana E.H. Wilson) at Imgeollyeong in Jirisan National Park. Jour. Natl Park Res. 2019a; 10(2):219-23.

Seo JW, Kim YJ, Choi EB, Park JH, Kim JH. Investigation of death years and interannual growth reduction of Korean firs (Abies koreana) at Yeongsil in Mt. Halla. J Korean Soc Environ Restoration Technol. 2019b;22(3):1-4.

Settele J, Scholes R, Betts R, Bunn S, Leadley P, Nepstad D, et al. Terrestrial and Inland Water Systems. In: Climate Change 2014: Impacts, Adaptation and Vulnerability. Part A: Global and Sectoral Aspects. Cambridge: Cambridge University Press; 2015. p. 271-360.

Shin MS, Seo C, Lee M, Kim JY, Jeon JY, Adhikari P, et al. Prediction of potential species richness of plants adaptable to climate change in the Korean Peninsula. J Environ Impact Assess. 2018;27(6):562-81.

Sohn JC, Kim SS, Choi SW. Three species of Epipleminae (Lepidoptera: Uraniidae) new to Korea, with a new synonym for Epiplema nubifasciaria Leech. Korean J Appl Entomol. 2019;58:63-8.

Sung JW, Kim KH. Changes of flowering time affected by climate change in the subalpine region of Mt. Gaya. J Agric Life Sci. 2018;52(1):13-23. https://doi. org/10.14397/jals.2018.52.1.13.

Yang JY, Kang SG, Le WH, Jeong MK. First record of Laysan albatross (Phoebastria immutabilis) in Korea. Korean J Ornithol. 2018;25(1):19-22. https://doi.org/10.3 0980/KJO.2018.06.25.1.19.

Yu JJ, Kim JS, Jang DH. A time-series analysis of the erosion and deposition around Halmi-Island, Baramarae. J Korean Geomorphological Assoc. 2016; 23(1):47-60. https://doi.org/10.16968/JKGA.23.1.4.

\section{Publisher's Note}

Springer Nature remains neutral with regard to jurisdictional claims in published maps and institutional affiliations.

Ready to submit your research? Choose BMC and benefit from:

- fast, convenient online submission

- thorough peer review by experienced researchers in your field

- rapid publication on acceptance

- support for research data, including large and complex data types

- gold Open Access which fosters wider collaboration and increased citations

- maximum visibility for your research: over $100 \mathrm{M}$ website views per year

At BMC, research is always in progress.

Learn more biomedcentral.com/submissions 